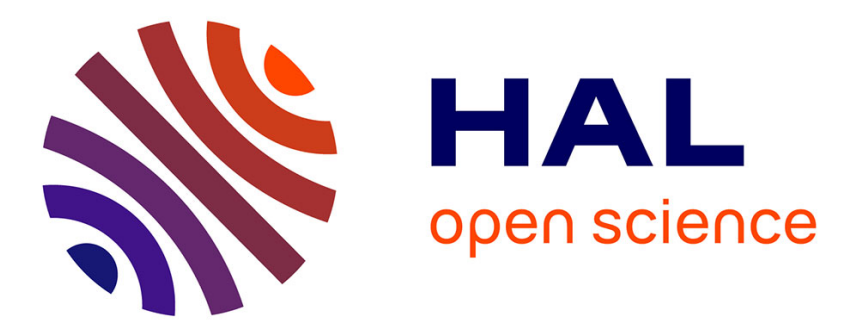

\title{
Forward to the north: two Euro-Mediterranean bumblebee species now cross the Arctic Circle
}

\author{
Baptiste Martinet, Pierre Rasmont, Bjorn Cederberg, Dimitri Evrard, Frode
} Odegaard, Juho Paukkunen, Thomas Lecocq

\section{To cite this version:}

Baptiste Martinet, Pierre Rasmont, Bjorn Cederberg, Dimitri Evrard, Frode Odegaard, et al.. Forward to the north: two Euro-Mediterranean bumblebee species now cross the Arctic Circle. Annales de la Société Entomologique de France, 2015, 51 (4), pp.303-309. 10.1080/00379271.2015.1118357 . hal01575789

\section{HAL Id: hal-01575789 \\ https://hal.univ-lorraine.fr/hal-01575789}

Submitted on 8 Dec 2020

HAL is a multi-disciplinary open access archive for the deposit and dissemination of scientific research documents, whether they are published or not. The documents may come from teaching and research institutions in France or abroad, or from public or private research centers.
L'archive ouverte pluridisciplinaire $\mathbf{H A L}$, est destinée au dépôt et à la diffusion de documents scientifiques de niveau recherche, publiés ou non, émanant des établissements d'enseignement et de recherche français ou étrangers, des laboratoires publics ou privés. 


\section{Forward to the North: two Euro-Mediterranean bumblebee species}

\section{now cross the Arctic Circle}

Baptiste Martinet ${ }^{1}$, Pierre Rasmont ${ }^{1}$, Björn Cederberg ${ }^{2}$, Dimitri Evrard ${ }^{1}$, Frode $\varnothing_{\text {degaard }}^{3}$, Juho Paukkunen ${ }^{4}$ and Thomas Lecocq ${ }^{1}$

${ }^{1}$ University of Mons, Research institute of Biosciences, Laboratory of Zoology, Place du Parc 20, 7000 Mons, Belgium

${ }^{2}$ Swedish Species Information Centre, Swedish University of Agricultural Sciences, PO Box 7007, 75007 Uppsala, Sweden

${ }^{3}$ Norwegian Institute for Nature Research - NINA, Postal address: P.O. Box 5685 Sluppen, NO-7485 Trondheim, Norway

${ }^{4}$ Finnish Museum of Natural History, Zoology Unit, P.O. Box 17, FI-00014 University of Helsinki, Finland

${ }^{*}$ Corresponding author: Baptiste.martinet@student.umons.ac.be

Abstract

In recent decades, several animal and plant species have been in regression (population size decrease and geographical distribution shrinking). This loss of biodiversity can be due to various factors such as the destruction and fragmentation of habitat, urban development, pesticides or climate change. However, some species benefit from these changes and expand their distribution. Here we report observations of two Euro-Mediterranean bumblebee species: Bombus terrestris for the first time and Bombus lapidarius, north of the Arctic Circle in Fennoscandia.

\section{Résumé}

Ces dernières décennies, de nombreuses espèces animales et végétales sont en régression autant d'un point de vue de leur distribution qu'au niveau de leur effectif 
de population. Cette perte de biodiversité peut être due à différents facteurs comme la destruction et la fragmentation de l'habitat, le développement urbain, les pesticides ou encore le changement climatique. Néanmoins, certaines espèces profitent de ces perturbations pour étendre leur distribution. C'est ainsi que pour la première fois, deux espèces Euro-Méditerranéennes de bourdons (B. terrestris et B. lapidarius) ont été observées en 2013 et 2014 en Fennoscandie au-delà du Cercle Arctique.

Keywords: Bombus terrestris, biogeography, climate change, Fennoscandia, heat wave

\section{Introduction}

Although bumblebees (genus Bombus Latreille) are distributed from Arctic tundra to lowland tropical forest, they are clearly most abundant (relative abundance) in alpine grassland habitats and cold and temperate regions of the Northern Hemisphere (Williams 1998). Indeed, these robust hairy bees have thermoregulatory adaptations involving facultative endothermy (Heinrich 1979), that enable them to live in the coldest areas inhabited by insects such as the Himalayas (Williams 1991), the Andes (Gonzalez et al. 2005) or north Greenland (Skorikov 1937), the Alps (Pradervand et al. 2011) and the Pyrenees (Iserbyt \& Rasmont 2012). They also reach a high diversity in Arctic regions (e.g. Fennoscandia: Skorikov 1937; Løken 1973 or Alaska: Williams 2014). In these high altitudes and latitudes, bumblebees are the only remaining bee pollinators, supporting a large part of the pollination ecosystem service (Shamurin et al. 1966; Kevan 1973). In recent decades, several animal and plant species have been in regression (population size decrease and geographical distribution shrinking). This loss of biodiversity can be due to various factors such as 
the destruction and fragmentation of habitat, urban development, pesticides or climate change.

However, their hotspot diversity areas (mountains, Arctic, Subarctic and Boreal regions) are also regions most severely affected by global warming (IPCC 2007; Franzén \& Ockinger 2011; Franzén \& Molander 2012), a phenomenon that will most likely increase during the next decades (Berger 1991; Settele et al. 2005; Spangenberg 2012). Climate change poses a major threat to many bumblebee species (Rasmont et al., 2015), however, some are able to benefit and expand their ranges.

Current and expected global warming consequences are the focus of many research projects (e.g. Parmesan \& Yohe 2003). One of the major consequences of global warming is species range displacement because organisms track their climatic niches as observed in several organisms (Parmesan \& Yohe 2003; Chen et al. 2011; Kuhlmann et al. 2012). However, since thermo-tolerance is species specific, species distribution shifts happen at different strength and speed (Klok \& Chown 2003; Franzén \& Ockinger 2011) resulting in new species communities and new interspecific interactions (Franzén \& Molander 2012). For native species, the interaction with climatic refugee species can lead to consequences similar to those fostered by invasive species (Inoue et al. 2008; Kanbe et al. 2008; Yoon et al. 2009; Nagamitsu et al. 2010; Meeus et al. 2011; Aizen et al. 2011; Thomas 2011; Arbetman et al. 2013a; Murray et al. 2013; Arbetman et al. 2013b). Therefore, an early detection of climatic refugee species through efficient faunistic surveys is important. We here report the observations of two Euro-Mediterranean bumblebee species (sensu de Lattin 1967) north of the Arctic Circle, a region hosting many bumblebee species 
with restricted areas. Specifically, we hypothesize the potential trigger factors and the potential consequences of the range shift to the North for Arctic biodiversity.

\section{Materials \& Methods}

\section{Determination of original northern European bumblebee fauna}

We focused on the region north of the Arctic Circle in Fennoscandia. We determined the original Arctic European bumblebee fauna (i.e. baseline dataset) according to (i) literature (Løken 1973) and (ii) occurrence observations before 1973. The occurrence observations were hosted by databases managed by B. Cederberg (Swedish Species Information Centre (SSIC), Sweden); F. Ødegaard (Norwegian Biodiversity Information Centre (NBIC) Norway); J. Paukkunen (Finnish Museum of Natural History (MZH), Finland) and P. Rasmont \& E. Haubruge (Banque de Données Faunique de Gembloux et de Mons (BDFGM), Belgium). These occurrence datasets were mapped using Data Fauna Flora software (Barbier et al. 2013)

\section{Detection of expanding species}

In order to assess potential changes in the northern European bumblebee fauna, we collected samples beyond the Arctic Circle (see sampling map Fig. 1) in 2013 and 2014 using entomological sweep nets. All individuals were killed by freezing. Males were prepared for chemotaxonomic analyses following De Meulemeester et al. (2011).

The specific identification was verified by checking different morphological diagnostic characters (Løken 1973, 1984; Rasmont 1984; Rasmont et al. 1986; Pekkarinen \& Kaarnama 1994). For the species belonging to the subgenus Bombus sensu stricto (Cameron et al. 2007), a group with low morphological differentiation, the morphological characters based on identification was assessed by comparing the GC-FID chromatograms of cephalic gland labial secretions (Lecocq et al. 2011) with 
reference specimens (Bombus terrestris: PRAS0006 from France, Var, Gonfaron 3.VII.2008, $43^{\circ} 18^{\prime} \mathrm{N}$ 06¹8'E; Bombus cryptarum: PRAS0148 from Sweden, Jämtland, Kvissle 15.VIII.2008, 63¹6’N 1356’E; PRAS0323 from Scotland, Wick, Wireless $12 . \mathrm{VIII} .2009,58^{\circ} 28^{\prime} \mathrm{N} 3^{\circ} 13^{\prime} \mathrm{W}$, see Fig. 1) and with the list of compounds given by Bertsch \& Schweer (2012a,b). The cephalic gland labial secretions are commonly used as diagnostic characters (Bertsch \& Schweer 2012a). We followed the preparation and analysis methods of De Meulemeester et al. (2011) and Lecocq et al. $(2011,2014,2015)$.

\section{Results}

A total of 756 specimens (17 species) were collected in the vicinity of Abisko (Sweden), and Narvik (Norway) in 2013, 1159 specimens (20 species) from Abisko (Sweden), Tarfala (Sweden) and Narvik (Norway) areas in 2014.

Among these specimens, we found two species previously unknown (unexpected) north of the Arctic Circle: B. lapidarius and B. terrestris. Another species B. wurflenii was observed far north of its baseline distribution (Løken 1973).

B. lapidarius (Fig. 2A): Abisko (Sweden), 68²1'10.3” N 1848'53.7” E, altitude 388 m asl, 22 VII 2013, $1 £$ on Trifolium pratense, leg. Martinet.

B. terrestris (Fig. 2B): Kiruna (Sweden), 6749'38.6” N 20²0’26.9” E, 446 m asl, 15 VII 2013, 1 \$ (BMAR0235) (Fig. 2B) on Epilobium angustifolium, leg. Martinet; Björkliden (Sweden), 68²4’36.9” N 18³9’16.9”E, 565 m asl, 21 VII 2014, 1 worker on Astragalus alpinus, leg. Rasmont; Narvik (Norway), Iptojávri, 6806’23.8” N 17²9’20.4” E, 620 m asl, 27 VII 2014, 1 \$ (PRAS1013) on Epilobium angustifolium, leg. Rasmont \& Martinet.

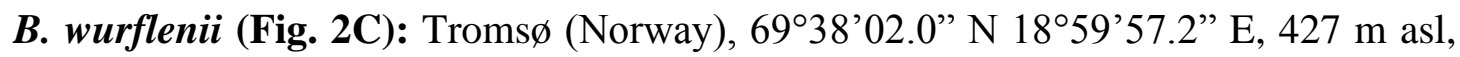
10 VII 2014, 2 workers on Vaccinium uliginosum, leg. Martinet \& Evrard. 
124 The comparison between the distribution of these species in the baseline dataset 125 (Løken 1973) and our new occurrence observations shows that B. lapidarius occurs 126 now $400 \mathrm{~km}$ north of its 1973 limits; B. terrestris occurs $800 \mathrm{~km}$ north of its 1973 127 limits and B. wurflenii now occurs $200 \mathrm{~km}$ north of its 1973 limits. All previous 128 reports of Bombus lapidarius and B. terrestris from north of the Arctic Circle (Fig. 1292 A, Fig. 2B) are of dubious provenance and remain unverified (see discussion). 130 

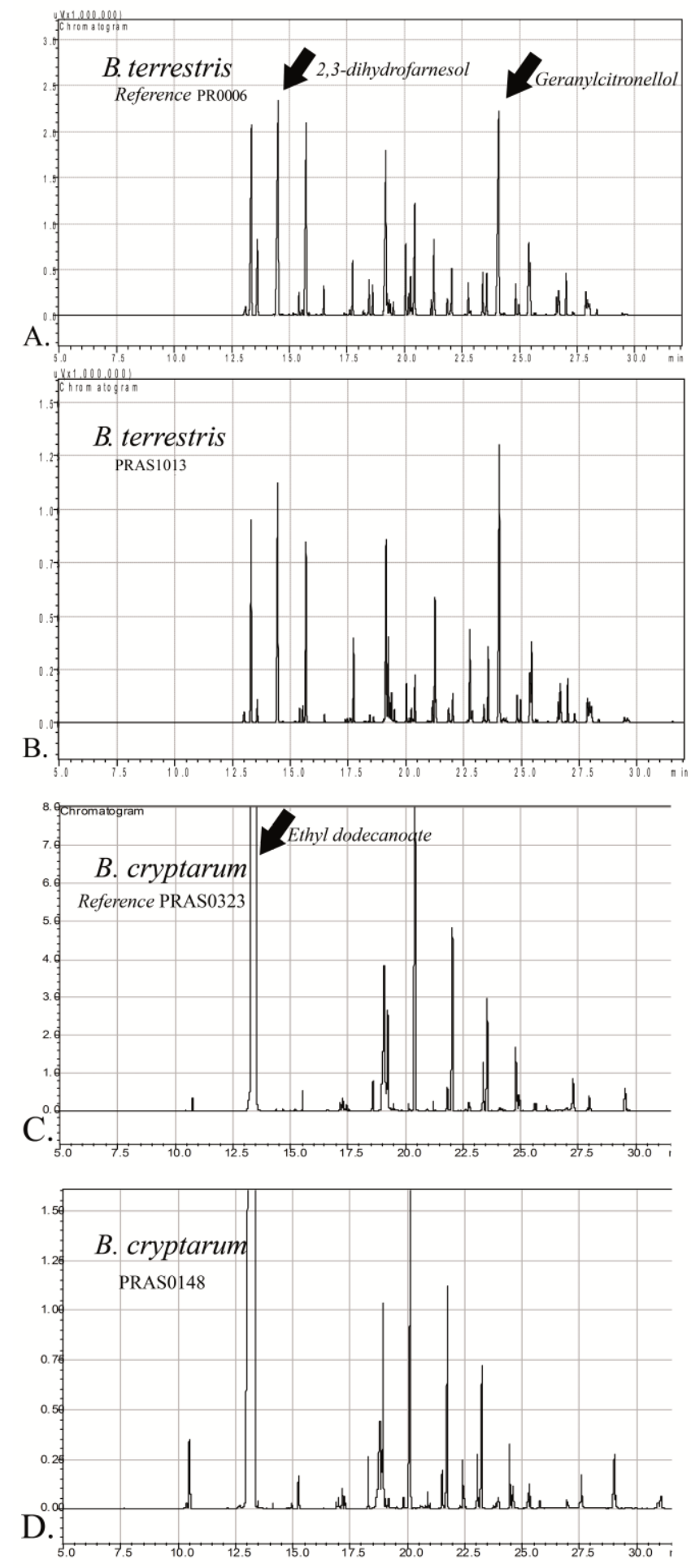

Figure 1. GC-FID chromatograms of Bombus sensu stricto males. (A) Reference specimen of B. terrestris (PRAS0006, Lecocq et al. 2013b). (B) Bombus terrestris male BMAR0235 (Kiruna). (C) Specimen of B. cryptarum male PRAS0323. (D) B. cryptarum male PRAS0148 (Jämtland, Sweden). 

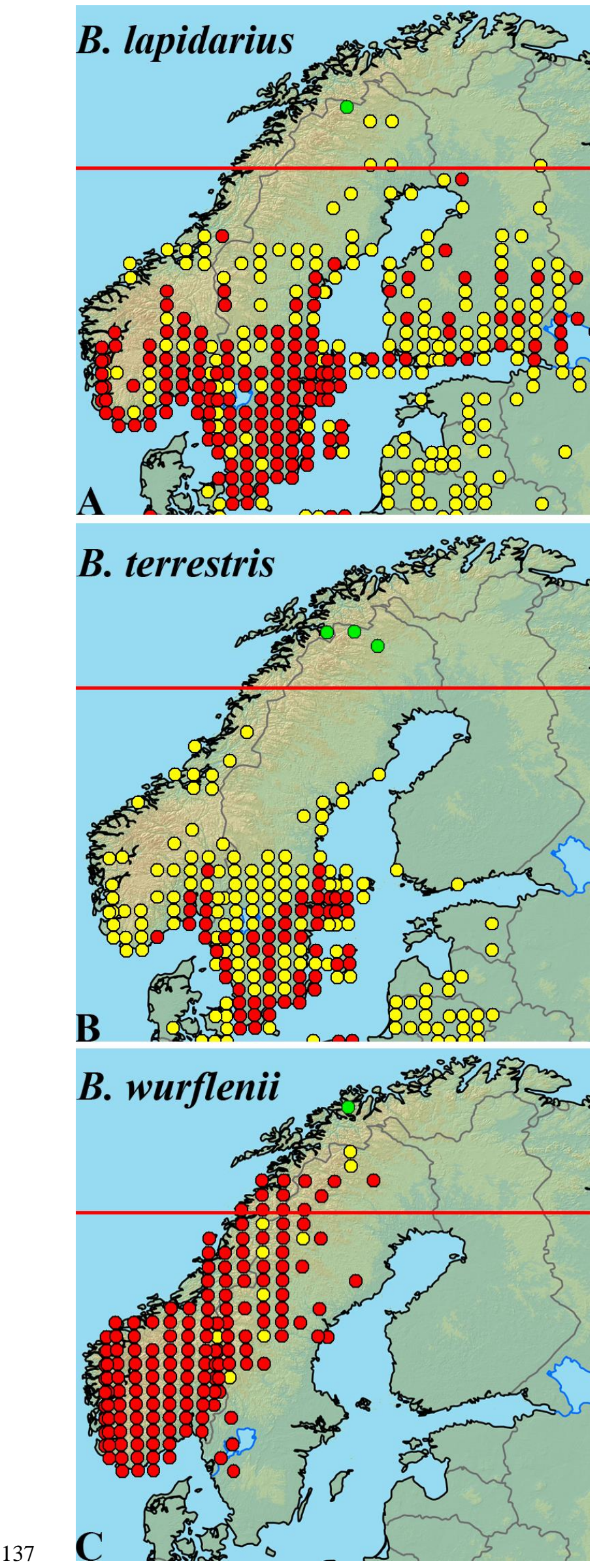
Figure 2. Maps summarizing the expansion toward the north of B. lapidarius (A), B. terrestris (B) and B. wurflenii (C). Red dots represent the presence of the species before 1974 (mainly Løken (1973) for Fennoscandia and Elfving (1968) for Finland) and yellow dots represent records from new sites of the species since 1974, which include data from BDFGM, MZH, NSIC, SSIC, Pekkarinen et al. (1981). Red dots are also used, if records from both periods $(>1974$ and $\leq 1974)$ are known from the same area (grid cell). Green dots represent our records of 2013 and 2014. The red line represents the Arctic Circle.

\section{Discussion}

\section{Toward a new Arctic bumblebee fauna?}

The eco-climatic ranges (e.g. geographical distribution) of different species are currently undergoing significant modifications. In bumblebees, many species are in regression (e.g. Williams 1986; Rasmont et al. 2005a; Cameron et al. 2011) while few species are expanding their distribution (e.g. B. semenoviellus: van der Smissen \& Rasmont, 2000; Sima \& Šmetana 2012; B. hypnorum: Roberts 2012; B. haematurus: Jenič et al. 2010; B. moderatus: Owen et al. 2012).

In Fennoscandia, our results show an obvious change in the northern European bumblebee fauna since the 1970s. The main change is the expansion of two EuroMediterranean species (B. lapidarius and B. terrestris) beyond the Arctic Circle. In the $1970 \mathrm{~s}$, the northern limit of $B$. terrestris barely reached Uppsala $\left(60^{\circ} \mathrm{N}\right)$ in Sweden or Hamar (north Oslo, 60 $50^{\prime} \mathrm{N}$ ) in Norway, while B. lapidarius was reaching higher latitudes, at the southernmost margin of the boreal taiga forest (Løken 1973). Our recent observations show that both species now reach the $68^{\circ} \mathrm{N}$ latitude, whereby they have crossed the Arctic Circle. It is important to note that several specimens of B. lapidarius have been collected in north Sweden before our sampling 
in 1976 (Løken 1978). This year corresponds to the most extreme climatic event (heat waves) of the last century in most of west Europe including the north of Fennoscandia (Klein 2009). Our hypothesis is that B. lapidarius is probably rare with a patchy distribution in the north of the Fennoscandia. However when the weather conditions are favourable for this species (temperature increase) it becomes more visible, perhaps more abundant or simply is more resistant to heat waves than the other species. So the sampling likelihood of $B$. lapidarius is higher during a particularly hot summer such as in 1976. The years 2013 and 2014 also provided heat waves in the north of Fennoscandia (Finnish Meteorological Institute 2013, 2014).

The expansion of Euro-Mediterranean bumblebee taxa toward the north has already been recorded in other regions. In Great Britain, B. terrestris was only recorded by Alford (1975) at the maximum latitude of Aberdeen $\left(57^{\circ} \mathrm{N}\right)$, while currently it reaches the northern coast of the Scotland $\left(60^{\circ} \mathrm{N}\right)$ (Roberts 2012 and Rasmont pers. obs.) and the Shetland (Macdonald 2014). In Russia, Panfilov (1957) observed only few specimens of $B$. terrestris in only one location in the Moscow region, while recently Levchenko (2012) found a large number of specimens in nearly all surveyed locations of this region. Such expansion has also been observed for B. veteranus which now crosses the Arctic Circle in Finland, Russia (e.g. in the Murmansk Oblast, Paukkunen \& Kozlov 2015) and in Sweden (Cederberg 2013).

The expansion of $B$. veteranus and B. wurflenii beyond the Arctic Circle could most likely be explained by the cold adaptations of these species (Løken 1973, Reinig 1988) and climate change. In contrast, B. lapidarius and B. terrestris are EuroMediterranean bumblebees. Indeed, B. terrestris is abundant all around the Mediterranean coast and reaches its southern limits on the edges of the Sahara (Rasmont et al. 2008). B. lapidarius has not been found as far south and it does not 
live on the Mediterranean coast, but it reaches the Atlas Mountains in Morocco (Rasmont \& Iserbyt 2014). Therefore, we suggest that the current global climate warming in northern regions could be the trigger factor of the expansion of such a species, as observed in other organisms (Rasmont et al. 2015).

An alternative hypothesis is that the Euro-Mediterranean species have not achieved equilibrium with their current environment (Svenning \& Skov 2007) and are still continuing their post Ice-Age expansion (Lecocq et al 2013a). Nevertheless the high dispersal ability of several bumblebee species such as B. lapidarius and B. terrestris (Kraus et al. 2009, Lepais et al. 2010), the long term occurrence of these species in surrounding regions (Rasmont \& Iserbyt 2014), as well as their phylogeographic structure (i.e. endemic haplotypes and high genetic diversity in Fennoscandia at least for B.lapidarius; Lecocq et al. 2013a; Lecocq et al. 2013b) make this hypothesis unlikely. Further studies on bumblebee climatic niches are needed to assess the role of climate change as a trigger factor of Euro-Mediterranean species expansion to cold regions. And finally, since $B$. terrestris is widely used and internationally traded for crop pollination, we cannot exclude that the collected $B$. terrestris individuals could have escaped from greenhouses. However, we did not observe any greenhouses in the surroundings of our study areas, the nearest ones being certainly more than $50 \mathrm{~km}$ distant.

\section{Consequences for Arctic species conservation}

Besides the understanding of factors triggering expansion, the consequences of the expansion of B. terrestris and B. lapidarius should be taken into account in local bumblebee conservation management. It remains to assess how B. lapidarius and $B$. terrestris could compete with the original high latitude bumblebee fauna where they forage side-by-side. However, both species are known for their large colonies (Holm 
1960; Velthuis \& van Doorn 2006) and for their high opportunism in foraging plant selection (Ruszkowski 1971; Teräs 1985; Rasmont 1988, Teper 2004). On the other hand, Arctic bumblebee species only establish small colonies with a low number of offspring (Løken 1973; Richards 1973; Berezin 1994, 1995). Therefore, Arctic bumblebee species already impacted by climatic stress (Franzén \& Ockinger 2011; Franzén \& Molander 2012; Martinet et al. 2015) could suffer from a drastic competition from the new Euro-Mediterranean invaders. As we are at the very initial stages of colonisation of these species, it is, as yet, difficult to project the future situation.

\section{Acknowledgements}

The authors thank the Abisko and Tarfala scientific stations (Sweden) for their welcome and their help in material collection. We acknowledge all the people that helped us in our journey to the Abisko and Tarfala stations: Peter Läkare and Gunhild Ninis Rosqvist (University of Stockholm), Magnus Augner and Linnéa Wanhatalo (Abisko Station), Hannele Savela (Oulu University, Interact administration), Josefine Strand and Therese Wikström (Länsstyrelsen i Norrbottens län Naturvårdsenheten, Luleå). The research has received funding from the European Community's Seventh Framework Programme (FP7/2007-2013) under grant agreement no 244090, STEP Project (Status and Trends of European Pollinators, www.step-project.net) and from the INTERACT FP-7 EU project. Special thanks to M. Franzen, Alrun Siebenkäs (UFZ, Halle) for their help. Thomas Lecocq has been working as a post-doc in the BELBEES project funded by the Belgian Scientific Politic (BELSPO, BR/132/A1/BELBEES).

\section{References}


Aizen MA, Lozada M, Morales CL. 2011. Comparative nectar-foraging behaviors and efficiencies of an alien and a native bumble bee. Biological Invasions 13: 2901-2909. doi: 10.1007/s10530-011-9972-3.

Alford D V. 1975. Bumblebees. London: Davis-Poynter, 352 p.

Arbetman MP, Meeus I, Morales CL, Alzen MA, Smagghe G. 2013a. Co-introduction and spillover of parasites by invasive Bombus terrestris. Bumblebee's chauffer hitchhike alien parasites when traveling to Patagonia, Argentina. Biological Invasions. Biodiversity Conservation 15: 489-494.

Arbetman MP, Meeus I, Morales CL, Alzen MA, Smagghe G. 2013b. Alien parasite hitchhikes to Patagonia on invasive bumblebee. Biological Invasions 15: 489494. doi: 10.1007/s10530-012-0311-0.

Barbier Y, Rasmont P, Dufrêne M, Sibert JM. 2014. Data fauna flora, Mons, Belgique : Université de Mons-Haintaut, http://hdl.handle.net/2268/148255

Berezin MV. 1994. Social organization of the bumblebees (Hymenoptera, Apoidea, Bombus) in the Arctic (Wrangel island), p. 320 in: Lenoir A., Arnold G., Lepage M. (Ed.), Les insectes sociaux, 12th Congress of the IUSSI-UIEIS, Paris.

Berezin M V. 1995. Geographical Diversity, Species Correlation, Population Structure and Cenotic Interactions of Arctic Bumble Bees (Apidae, Bombus), p. 205-215 in: Grönlund E., Melander O., Swedish-Russian Tundra Ecology. Expedition-94. Stockholm: Swedish Polar Research Secretariat.

Berger A, Loutre M F. 1991. Insolation values for the climate of the last 10 million years. Quaternary Science Reviews 10: 297-317. 
Bertsch A, Schweer H., 2012a. Male labial gland secretions as species recognition signals in species of Bombus. Biochemical Systematics and Ecology 40 (2012) 103-111

Bertsch A, Schweer H., 2012b. Cephalic labial gland secretions of males as species recognition signals in bumblebees: are there really geographical variations in the secretions of the Bombus terrestris subspecies? (Hymenoptera: Apidae: Bombus). Beiträge zür Entomologie, 62(1): 103-124.

Cameron SA, Hines H.M., Williams P.H. 2007. A comprehensive phylogeny of the bumble bees (Bombus). Biological Journal of the Linnean Society 91: 161188.

Cameron SA, Lozier J D, Strange J P, Koch J B, Cordes N, Solter L F, Griswold T L. 2011. Patterns of widespread decline in North American bumble bees. Proceedings of the National Academy of Sciences 108(2): 662-667.

Cederberg B, 2013. Artfaktblad Bombus veteranus sandhumla. Artdatabanken, SLU, Uppsala, Sweden. http://www.artfakta.se/artfaktablad/Bombus_Veteranus_102704.pdf (accessed 16.XII.2014).

Chen I-C, Hill JK, Ohlemüller R, et al. 2011. Rapid range shifts of species associated with high levels of climate warming. Science 333: 1024-1026. doi: 10.1126/science.1206432.

Core Writing Team, Pachauri R K and Reisinger A (Eds.). IPCC. 2007. Contribution of Working Groups I, II and III to the Fourth Assessment Report of the Intergovernmental Panel on Climate Change, Geneva, Switzerland.104p.

de Lattin G. 1967. Grundiss der Zoogeographie. Iena, Stuggart: Gustav Fisher, 602 p. 
De Meulemeester T., Gerbaux P., Boulvin M., Coppée A., Rasmont P. 2011. A simplified protocol for bumble bee species identification by cephalic secretion analysis. Insectes Sociaux 58: 227-236.

Elfving R. 1968. Die Bienen Finnlands. Fauna Fennica 21: 1-69.

Finnish Meteorological Institute 2013. June was exceptionally warm. http://en.ilmatieteenlaitos.fi/press-release/730379 (acceded 13.02.2015).

Finnish Meteorological Institute 2014. An exceptionally long heatwave . http://en.ilmatieteenlaitos.fi/press-release/10014539 (acceded 13.02.2015).

Franzén M, Ockinger E. 2011. Climate-driven changes in pollinator assemblages during the last 60 years in an Arctic mountain region in Northern Scandinavia. Journal of insect conservation 16: 227-238.

Franzén M, Molander M. 2012. How threatened are alpine environments? a cross taxonomic study. Biodiversity and Conservation 21: 517-526.

Gonzalez VH, Ospina M, Bennett D. 2005. Abejas altoandinas de Colombia: Guía de campo. Bogotà : Instituto de Investigación de Recursos Biológicos Alexander von Humboldt, 80p.

Heinrich B. 1979. Bumblebee economics. Cambridge, Massachussets: Harvard University Press, 256p.

Holm SN. 1960. Experiments on the domestication of bumblebees (Bombus Latr.) in particular B.lapidarius L. and B.terrestris L. Royal Veterinary and Agriculture College Copenhagen Yearbook 1960: 1-19.

Inoue MN, Yokoyama J, Washitani I. 2008. Displacement of Japanese native bumblebees by the recently introduced Bombus terrestris (L.) (Hymenoptera: Apidae). Journal of Insect Conservation 12: 135-146. 
Iserbyt S, Rasmont P. 2012. The effect of climatic variation on abundance and diversity of bumblebees: a ten years survey in a mountain hotspot. Annales de la Société entomologique de France (n.s.) 48: 261-273.

Jenič A., Gogala A., Grad J. 2010. Bombus haematurus (Hymenoptera: Apidae), new species in the Slovenian bumblebee fauna. Acta entomologica slovenica 18(2): 168-170.

Kevan P G. 1973. Flowers, insects, and pollination ecology in the Canadian high Arctic. Polar Record 16: 667-674.

Kanbe Y, Okada I, Yoneda M, et al. 2008. Interspecific mating of the introduced bumblebee Bombus terrestris and the native Japanese bumblebee Bombus hypocrita sapporoensis results in inviable hybrids. Naturwissenschaften 95: 1003-1008.

Klein T. 2009. Comparaison des sécheresses estivales de 1976 et 2003 en Europe occidentale à l'aide d'indices climatiques. Bulletin de la Société géographique de Liège 53 : 75-86.

Klok JC, Chown S.L. 2003. Resistance to temperature extremes in sub-Antarctic weevils, interspecific variation, population differentiation and acclimation. Biological Journal of the Linnean Society 78: 401-414.

Kraus FB, Wolf S, Moritz RFA. 2009. Male flight distance and population substructure in the bumblebee Bombus terrestris. Journal of Animal Ecology 78: $247-252$.

Kuhlmann M, Guo D, Veldtman R, Donaldson J. 2012. Consequences of warming up a hotspot: Species range shifts within a centre of bee diversity. Diversity and Distributions 18: 885-897. 
Lecocq T, Lhomme P, Michez D, Dellicour S, Valterová I, Rasmont P. 2011. Molecular and chemical characters to evaluate species status of two cuckoo bumblebees: Bombus barbutellus and Bombus maxillosus (Hymenoptera, Apidae, Bombini). Systematic Entomology 36: 453-469.

Lecocq T, Dellicour S, Michez D, Lhomme P, Vanderplanck M, Valterova I, Rasplus JY, Rasmont P. 2013a. Scent of a break-up: phylogeography and reproductive trait divergences in the red-tailed bumblebee (Bombus lapidarius). BMC Evolutionary Biology 13:263. doi: 10.1186/1471-2148-13-263

Lecocq T, Vereecken N, Michez D, Dellicour S, Lhomme P, Valterovà I, Rasplus JY, Rasmont P. 2013b. Patterns of genetic and reproductive traits differentiation in Mainland vs. Corsican populations of bumblebees. PLoS One 8:e65642. doi: 10.1371/journal.pone.0065642

Lecocq T, Brasero N, De Meulemeester T, Michez D, Dellicour S, Lhomme P, de Jonghe R, Valterová I, Urbanová K, Rasmont P. 2014. An integrative taxonomic approach to assess the status of Corsican bumblebees: implications for conservation. Animal Conservation. in press. DOI: 10.1111/acv.12164.

Lecocq T, Dellicour S, Michez D, Dehon M, Dewulf A, De Meulemeester T, Brasero N, Valterová I, Rasplus JY, Rasmont P. Methods for species delimitation in bumblebees (Hymenoptera, Apidae, Bombus): towards an integrative approach. Zoologica Scripta. in press.

Lepais O, Darvill B, O’Connor S, Osborne JL, Sanderson RA, Cussans J, Goffe L, Goulson D. 2010. Estimation of bumblebee queen dispersal distances using sibship reconstruction method. Molecular Ecology 19: 819-831.

Levchenko TV. 2012. Materialy po faune pchel (Hymenoptera: Apoidea) Moskovskoj oblasti. 3. Semejstvo Apidae. Rod Bombus Latreille, 1802. [Contributions to 
the fauna of bees (Hymenoptera: Apoidea) of Moscow Province. 3. Family Apidae. Genus Bombus Latreille, 1802]. Eversmannia 31/32: 72-88 (In Russian).

Løken A. 1973. Studies on Scandinavian bumble bees (Hymenoptera, Apidae). Norsk Entomologisk Tidsskrift 20: 1-218.

Løken A. 1978. Notes on the Scandinavian fauna of social Aculeates (Hym., Vespidae and Apidae s.s.). Norwegian Journal of Entomology Tidsskrift 25: 165-170

Løken A. 1984. Scandinavian species of the genus Psithyrus Lepeletier (Hymenoptera: Apidae). Entomologica Scandinavica, suppl. 23: 1-45.

Martinet B, Lecocq T, Smet J, Rasmont P. 2015. A protocol to assess insect resistance to heat waves, applied to bumblebees (Bombus Latreille, 1802), PLOSONE, in press

Macdonald MA. 2014. Buff-tailed Bumblebee Bombus terrestris in Shetland. BWARS Newsletter 20: 20-22.

Meeus I, Brown MJF, De Graaf DC, Smagghe G. 2011. Effects of Invasive Parasites on Bumble Bee Declines. Conservation Biology 25: 662-671.

Murray TE, Coffey MF, Kehoe E, Horgan FG. 2013. Pathogen prevalence in commercially reared bumble bees and evidence of spillover in conspecific populations. Biological Conservation 159: 269-276. doi: 10.1016/j.biocon.2012.10.021.

Nagamitsu T, Yamagishi H, Kenta T, Inari N, Kato E. 2010. Competitive effects of the exotic Bombus terrestris on native bumble bees revealed by a field removal experiment. Population Ecology 52: 123-136.

Owen R. E, Otterstatter MC, Carter RV, Farmer A, Colla SR, O'Toole N. 2012. Significant expansion of the distribution of the bumble bee Bombus 
moderatus (Hymenoptera: Apidae) in Alberta over twenty years. Canadian Journal of Zoology 90: 133-138.

384

Panfilov D.V. 1957. Shmeli (Bombidae) Moskovskoj oblasti. [The bumble bees (Bombidae) of the Moscow province]. Uchenye Zapiski moskovskogo gorodskogo pedagogicheskogo instityta V.P. Potemkina 65(6): 191-219 (In Russian).

Paukkunen J. \& Kozlov, M. V. 2015. Stinging wasps, ants and bees (Hymenoptera: Aculeata) of the Murmansk region, Northwest Russia. - Entomologica Fennica 26, in press.

Parmesan C, Yohe G. 2003. A globally coherent fingerprint of climate change impacts across natural systems. Nature 421: 37-42. doi: 10.1038/nature01286.

Pekkarinen A, Teräs I, Viramo J, Paatela J 1981. Distribution of bumblebees (Hymenoptera, $\quad$ Apidae: Bombus and Psithyrus) in eastern Fennoscandia. Notulae Entomologicae 61: 71-89.

Pekkarinen A, Kaarnama E. 1994. Bombus terrestris auct. new to Finland (Hymenoptera, Apidae). Sahlbergia 1: 11-13.

Pradervand J-N, Pellissier L, Rossier L, Dubuis A, Guisan A, Cherix D. 2011. Diversity of bumblebees (Bombus Latreille, Apidae) in the Alps of the canton Vaud (Switzerland). Mitteilungen der Schweizerischen Entomologischen Gesellschaft 84: 45-66.

Rasmont P. 1984. Les bourdons du genre Bombus Latreille sensu stricto en Europe Occidentale et Centrale (Hymenoptera, Apidae). Spixiana, München 7 : 135160.

Rasmont P, Scholl A, De Jonghe R, Obrecht E, Adamski A. 1986. Identité et variabilité des males de Bourdons du genre Bombus Latreille sensu stricto en 
Europe occidentale et centrale (Hymenoptera, Apidae, Bombinae). Revue suisse de zoologie 93: 661-682.

Rasmont P. 1988. Monographie écologique et zoogéographique des Bourdons de France et de Belgique (Hymenoptera, Apidae, Bombinae). Thèse de doctorat en Sciences Agronomiques, Gembloux : Faculté des Sciences agronomiques de l'Etat, $310+$ LXII p.

Rasmont P, Pauly A, Terzo M, Patiny S, Michez D, Iserbyt S, Barbier Y, Haubruge E. 2005. The survey of wild bees (Hymenoptera, Apoidea) in Belgium and France. Roma: Food and agriculture organization of the United Nations, http://www.gembloux.ulg.ac.be/entomologie-fonctionnelle-et-evolutive/wpcontent/uploads/2012/07/1597.pdf.

Rasmont P, Coppée A, Michez D, De Meulemeester T. 2008. An overview of the Bombus terrestris (L. 1758) subspecies (Hymenoptera: Apidae). Annales de la Société entomologique de France (n. s.) 44 (2): 243-250.

Rasmont P, Iserbyt S. 2014. Atlas of the European Bees: genus Bombus. 3d Edition. STEP Project. Status Trends Eur Pollinators, Atlas Hymenoptera, Mons, Gembloux. http://www.zoologie.umh.ac.be//hymenoptera/page.asp?ID=169.

Rasmont P, Franzen M, Lecocq T, Harpke A, Castro L, Cederberg B, Dvorak L, Fitzpatrick U, Gonseth Y, Haubruge E, Mahé G, Manino A, Neumayer J, Ødegaard F, Roberts SPM, Paukkunen J, Pawlikowski T, Reemer M, Straka J, Schweiger O. 2015. Climatic Risk and Distribution Atlas of European Bumblebees. Sofia: Pensoft, 236p.

Reinig WF, Rasmont P. 1988. Beitrag zur Kenntnis der Bergwaldhummel Alpigenobombus wurfleini (Radoszkowski, 1859) (Hymenoptera, Apidae, Bombinae). Spixiana, München 11(1): 37-67. 
Richards K W. 1973. Biology of Bombus polaris Curtis and B. hyperboreus Schönherr at lake Hazen, Northwest Territories (Hymenoptera: Bombini). Quaestiones entomologicae. 9: 115-157.

Roberts S. 2012. Information sheet: Tree bee (Bombus hypnorum). Hymettus (BWARS).

Ruszkowski A. 1971. Food plants and economical importance of Bombus terrestris (L.) and B. lucorum (L.). Pamietnik Pulawski 47: 215-250.

Settele J \& al. (Alarm Project). 2005. Alarm: Assessing Large-scale environmental Risks for biodiversity with tested Methods. Ecological Perspectives for Science and Society 14(1): 69-72.

Shamurin V F. 1966. Rol' nasekomikh-opilitelei v tundrovikh soobshchestvakh. [The role of insects in tundra communities]. Organizmi iprirodnayasreda. Voprosi geographii. 69: 98-117. (in Russian).

Skorikov AS. 1937. Die grönländischen Hummeln im Aspekte der Zirkumpolarfauna. Entomologiske Meddelelser 20: 37-64.

Šima P, Smetana. 2012. Bombus (Cullumanobombus) semenoviellus (Hymenoptera: Apidae: Bombini) new species for the bumble bee fauna of Slovakia. Klapalekiana 48: 141-147.

Spangenberg J H, Carter T R, Fronzek S, Jaeger J, Jylhä K, Kühn I, Omann I, Paul A, Reginster I, Rounsevell M, Stocker A, Sykes M T, Settele J. 2012. Scenarios for investigating risks to biodiversity. Global Ecology and Biogeography 21(1): 5-18.

Svenning J-C, Skov F. 2007. Could the tree diversity pattern in Europe be generated by postglacial dispersal limitation? Ecological Letters 10: 453-60. doi: 10.1111/j.1461-0248.2007.01038.x. 
Teper D. 2004. Comparison of food plants of Bombus terrestris L. and Bombus lapidarius L. based on pollen analysis of their pollen loads. Journal of Apicultural Science 49 (2): 43-50.

Teräs I. 1985. Food plants and flower visits of bumblebees (Bombus: Hymenoptera, Apidae) in southern Finland. Acta Zoologica Fennica 179: 1-120.

Thomas C D. 2011. Translocation of species, climate change, and the end of trying to recreate past ecological communities. Trends in Ecology and Evolution 26(5): 216-221.

van der Smissen, J. \& P. Rasmont. 2000. Bombus semenoviellus Skorikov 1910, eine für Westeuropa neue Hummelart (Hymenoptera: Bombus, CullumanoBombus). Bembix 13: 21-24.

Velthuis HHW, van Doorn A. 2006. A century of advances in bumblebee domestication and the economic and environmental aspects of its commercialization for pollination. Apidologie 37: 421-451.

Williams PH. 1986. Environmental change and the distribution of British bumble bees (Bombus Latr.). Bee world. 67(2): pp.50-61.

Williams PH. 1991. The bumble bees of the Kashmir Himalaya (Hymenoptera: Apidae, Bombini). Bulletin of the British Museum of Natural History (Entomology). 60: 1-204.

Williams PH. 1998. An annotated checklist of bumble bees with an analysis of patterns of description (Hymenoptera: Apidae, Bombini). Bulletin of the British Museum (Natural History). 67: 79-152.

Williams PH., Thorp R, Richardson L, Colla S. 2014. Bumble Bees of North America. New Jersey: Princeton University Press, 208 p. 
481 Yoon HJ, Sohn MR, Choo YM, Li J, Sohn HD, Jin BR. 2009. Defensing gene sequences of three different bumblebees, Bombus spp. Journal of Asia-Pacific Entomology 12: 27-31. 